\title{
Morphological characterization, cytogenetic analysis, and geographical distribution of the Pygmy Marbled Newt Triturus marmoratus pygmaeus (Wolterstorff, 1905) (Caudata: Salamandridae)
}

\author{
M. García-París, P. Herrero, C. Martín, J. Dorda, M. Esteban \& B. Arano \\ Museo Nacional de Ciencias Naturales, José Gutiérrez Abascal 2, E-28006 Madrid, Spain
}

Keywords: Taxonomy, cytogenetics, Salamandridae, Triturus, Iberian Peninsula

\begin{abstract}
Triturus marmoratus pygmaeus, a problematic subspecies of the Marbled Newt from the southern part of the Iberian Peninsula, is redescribed using specimens collected in the "typical" area. Diagnostic external morphological features are provided to permit the accurate determination of the specimens belonging either to $T . m$. marmoratus or to $T . m$. pygmaeus. These diagnostic features were applied to individuals both from the field and from museum collections. The results indicate a larger distributional area for $T . m$. pygmaeus than was previously recognized. The distribution of $T$. m. marmoratus ranges over the northern half of the Iberian Peninsula and most of France; $T$. m. pygmaeus occupies the southwestern part of the Iberian Peninsula. The contact area between the two subspecies seems to be located along the Central Range Mountains (Sistema Central) in Portugal and Spain. T. m. marmoratus extends southwards beyond this borderline in three areas: Serra da Estrela (Portugal), Sierra de Gata (Spain) and Sierra de Guadarrama (Spain). The only point at which $T$. $m$. pygmaeus reaches northwards beyond the Central System is near Puerto de Malagón (Madrid Province, Spain). No cases of strict sympatry, nor individuals with intermediate morphological features have been observed. The results of an extensive cytogenetical analysis do not show any differences between $T . m$. pygmaeus and $T . m$. marmoratus. Interestingly, however, the $T$. $m$. pygmaeus populations from Doñana (Huelva Province, Spain) showed an exclusive, though little differentiated, $\mathrm{C}$-banding pattern.
\end{abstract}

\section{Resumen}

Se redescribe Triturus marmoratus pygmaeus, una subespecie problemática de tritón jaspeado del sur de la Península Ibérica, utilizando para ello especímenes procedentes de su área "típica". Se definen caracteres morfológicos externos que permiten la identificación de los individuos pertenecientes a $T$. m. mar- moratus o a T. m. pygmaeus. Estos rasgos se aplican a series de individuos procedentes de colecciones cientificas o bien observados directamente sobre el terreno. Como consecuencia de la aplicación de estos criterios, el área de distribución de $T . m$. pygmaeus se extiende considerablemente hacia el norte. La distribución de $T$. $\boldsymbol{m}$. marmoratus incluye la mitad septentrional de la Península Ibérica y la mayor parte de Francia, mientras que $T$. $m$. pygmaeus ocupa una amplia porción en la región sudoccidental de la Península Ibérica. La zona de contacto entre ambas subespecies parece localizarse a lo largo del Sistema Central en Portugal y España. T. m. marmoratus sobrepasa hacia el sur el Sistema Central en tres áreas: Serra da Estrela (Portugal), Sierra de Gata (España) y Sierra de Guadarrama (España). El único punto en el que $T . m$. pygmaeus sobrepasa hacia el norte estas montañas, se sitúa en las proximidades del Puerto de Malagón (Madrid, España). No se han observado casos de simpatría estricta, ni individuos con rasgos intermedios entre ambas subespecies. Los resultados de un extenso análisis citogenético no muestran la existencia de diferencias entre $T . m$. marmoratus y $T$. $m$. pygmaeus, si bien la población de $T$. $m$. pygmaeus de Doñana (Huelva, España) muestra un patrón particular, aunque poco diferenciado, de bandas $\mathrm{C}$.

\section{Introduction}

The marbled newt Triturus marmoratus (Latreille, 1800), occurs over a large part of western Europe, from northwestern and central France in the north to southern Portugal and southwestern Spain in the south. Most authors accept the existence of two subspecies, $T$. m. marmoratus, widely spread over most of the area described, and $T . m$. pygmaeus (Wolterstorff, 1905), which is limited to the southern part of the Iberian Peninsula (Macgregor et al., 1990). 
Table I. External measurements (in mm) of specimens of $T . m$. marmoratus from Cantabria and $T$. m. pygmaeus from Cádiz (Spain). Variables measured are: TL = total length; SV = snout-vent length; FHL = distance between forelimbs and hindlimbs; FLL = forelimb length; $3 F F=$ third finger length; $H L L=$ hindlimb length; $3 H F=$ third toe length; $H W=$ head width; HL = head length.

\begin{tabular}{|c|c|c|c|c|c|c|c|c|c|c|}
\hline & & TL & SV & FHL & FLL & 3FF & HLL & $3 \mathbf{H F}$ & HW & HL \\
\hline \multicolumn{11}{|c|}{$T . m$. marmoratus } \\
\hline Males & mean & 132.1 & 72.9 & 37.5 & 29.3 & 8.8 & 28.5 & 9.5 & 12.8 & 15.6 \\
\hline$n=20$ & SD & 9.04 & 6.16 & 2.90 & 2.56 & 1.2 & 2.86 & 1.0 & 1.20 & 1.72 \\
\hline Females & mean & 148.4 & 81.5 & 47.2 & 29.7 & 7.9 & 29.2 & 8.0 & 14.3 & 17.9 \\
\hline$n=15$ & SD & 10.45 & 5.47 & 3.69 & 2.82 & 0.9 & 1.83 & 0.7 & 1.22 & 1.48 \\
\hline \multicolumn{11}{|c|}{ T. m. pygmaeus } \\
\hline Males & mean & 106.5 & 59.4 & 28.9 & 21.6 & 6.5 & 11.7 & 7.2 & 10.7 & 15.1 \\
\hline$n=15$ & SD & 9.02 & 5.35 & 4.45 & 1.63 & 0.8 & 1.77 & 0.7 & 1.21 & 1.42 \\
\hline Females & mean & 116.5 & 61.1 & 33.7 & 21.0 & 5.8 & 20.9 & 6.0 & 11.8 & 15.9 \\
\hline$n=10$ & SD & 5.01 & 3.17 & 2.15 & 1.28 & 0.8 & 1.35 & 0.4 & 0.85 & 1.58 \\
\hline
\end{tabular}

The most recent studies on the morphology, immunology, and genetics of $T$. marmoratus and allied species (Dorda \& Esteban, 1986; Busack et al., 1988; Macgregor et al., 1990) point to the complexity of the group and suggest that a revision of the taxonomic status of $T$. m. pygmaeus may be appropriate.

One of the problems is the difficulty in correctly identifying individuals belonging to each subspecies. This seems partly due to the lack of reliable diagnostic features, as well as to an extended misinterpretation of Wolterstorff's (1905) abbreviated description of $T$. $m$. pygmaeus. This misinterpretation arises from the confusion of the extremely small size of specimens of the coastal populations from southwestern Spain with that of the small individuals originally described by Wolterstorff (1905).

In the present study the southern subspecies (T. $m$. pygmaeus) is redescribed using specimens from the "typical" area. Some diagnostic morphological and cytogenetic features of T. m. pygmaeus are proposed that allow its correct identification. The diagnostic features are applied to individuals collected in the field and from museum collections and the resultant distributional limits are indicated.

\section{Material and methods}

Twenty-five specimens, collected during their aquatic phase in San Roque and Los Barrios (Algeciras Bay, Cádiz Province, Spain), were used for the redescription of $T . m$. pygmaeus. These capture sites were selected by consideration of two facts: firstly, the "terra typica restricta" for $T . m$. pygmaeus as reported by Mertens \& Müller (1928) is Cádiz, and within the Cádiz Province, Algeciras is one of the two sites mentioned by Wolterstorff (1905). Secondly, the external features of the individuals from these populations are similar to those indicated by Wolterstorff in the original description.

Thirty-five $T . m$. marmoratus individuals from different sites in Cantabria (northern Spain) were used as specimens for comparison in order to establish the diagnostic features of $T . m$. pygmaeus. Some individuals of both groups were kept alive until the end of the breeding period in order to describe their colouration during the terrestrial phase. Measurements and description of external features and colouration were all made on live specimens. External measurements are indicated in Table I. Statistical analysis is restricted here to the use of the $t$-test for comparison of mean values (Zar, 1984).

Once the diagnostic features were established, we proceeded to revise the material available from some museum collections and to conduct a field inspection of selected populations (cf. Appendix). After the subspecific assignation, 255 specimens from diverse localities were measured preserved or alive. A two-group comparison of the resultant $T . m$. marmoratus and $T . m$. pygmaeus samples was conducted using stepwise discriminant analysis from the Discriminant program package of BMDP (Dixon, 1975). Total length was excluded from this analysis.

For use in cytogenetic analysis, 80 males and 73 females from 22 localities were intraperitoneally injected with $0.05 \mathrm{ml}$ of a 
$0.1 \%$ colchicine solution per gram of body weight, $24 \mathrm{~h}$ before they were sacrified. Testes and intestine were removed and placed in $0.05 \mathrm{M} \mathrm{KCl}$ for 5 minutes, subsequently fixed in a solution of ethanol and acetic acid (3:1) for a minimum of $48 \mathrm{~h}$, and then stored in $70 \%$ ethanol at $4^{\circ} \mathrm{C}$. Preparations of mitotic chromosomes were made using the squash technique and were air dried after immersion in liquid nitrogen. The slides were processed following the $\mathrm{C}$-banding method described by Sumner (1972) with slight modification: incubation time in freshly saturated $\mathrm{Ba}(\mathrm{OH})_{2}$ solution was $5 \mathrm{~min}$. at $60^{\circ} \mathrm{C}$. They were then rinsed in $1 \%$ acetic acid solution for $5 \mathrm{~min}$. The slides obtained were incubated in $2 \times \mathrm{SSC}$ at $60^{\circ} \mathrm{C}$ for $30 \mathrm{~min}$. Finally, preparations were rinsed in distilled water and stained with $3 \%$ Giemsa in phosphate buffer, pH 6.8. Giemsa stained preparations were photographed with a Zeiss Universal microscope using Kodak Imagecapture AHU microfilm.

All specimens examined and their localities are listed in the Appendix.

\section{Results}

\section{External morphology}

Redescription of $T . m$. pygmaeus. - Large head, longer than wide, gradually sharpened, ending abruptly in a narrow, blunt nose. Small eyes placed in a forward position. Prominent gular fold. Elongated body with long, thin legs. Digits long, especially in males. Toe webbing absent. Relatively short tail, its cross-section being almost cylindrical at the base and progressively compressed towards the tip. Finely granulated skin, ridged in the gular region, with large granules unevenly spread over the dorsal surface. Well developed labial folds during the aquatic phase. During the breeding period the males have a relatively low linear dorsal crest, which continues along the tail without interruption or any notable inflexion in the pelvic area.

During the terrestrial phase the dorsal colour pattern consists of an irregular pattern of black spots on a green background. These spots can create a reticulum or a more or less wide band running along the side of the body. In the females, the dorsal midline appears as a continuous red-orange stripe. Males, however, have a line with alternating orange-yellow and black narrow bands instead of the stripe. The dorsal part of the tail shows the same colour as the dorsum. Ventrally, the colouration is that of a light yellowish background with an orange hue on which several large blackish spots and white dots may be found. These white dots usually show a higher density on the flanks and occasionally completely cover the background colouration. White dots are also present on the base of the flanks, spreading over the sides of the neck and the cheeks, here alternating with black spots. The ventral dark spots are usually large and roundish in males and small and more elliptically shaped in females. The ventral background colour continues over the gular region. Juveniles show a similar but brighter colour than adults. In all juvenile specimens studied, a conspicuous orange-red dorsal line, green dorsal hues, and a yellowish ventral colouration are present.

During the aquatic phase, the male dorsal colouration changes drastically. The black spots get lighter, becoming brown or bronzed with broad blackish dots in the middle. Occasionally, portions of the terrestrial-phase spots become mixed with the rest of the dorsal colouration, which sometimes show as cupreous or bronze tones on a green background (an example of this pattern can be seen in Andrada, 1980: plate 33). Some individuals may become completely dark and melanic in appearance; females may show evenly-spread green-grey hues. The inferior caudal crest is black in the male, with some white dots. In the female, the lower part of the crest usually shows orange-yellowish, or greyish tones.

To complete the description, some basic statistical parameters related to total length, snout-vent length, distance between forelimbs and hindlimbs, forelimb length, third finger length, hindlimb length, third toe length, head width, and head length are indicated for each sex in Table $I$.

Comparison of $T . m$. marmoratus and $T . m$. pygmaeus. - The comparative analysis of $T . m$. pygmaeus from Cádiz and $T$. m. marmoratus from Cantabria shows the following diagnostic features for $T . m$. pygmaeus:

- Size: $T$. m. pygmaeus is smaller in size than $T$. m. marmoratus (Table I), whether using natural log-transformed (Lemen, 1983) or non-transformed data. In all the variables studied, with the 
exception of head length, there are highly significant differences $(p<0.01)$ between the two groups of populations. Although all these measurements could be used as diagnostic feature of either group, we propose snout-vent length as the simplest one, because there is hardly any overlap between the two groups studied, and it is easily measured both in museum specimens and in the field.

Results from the a posteriori discriminant analysis of the log-transformed data set from the $\mathbf{3 1 5}$ specimens measured, show effective separation for the two subspecies. Histograms of discriminant scores demonstrate a clear separation of the subspecies with only slight overlap (Fig. 5). Results for the original data set are practically identical to those for the transformed data.

- Ventral colouration: typically creamy yellow in T. m. pygmaeus, marked to a greater or lesser extent with large black spots and small white ones. In $T$. $m$. marmoratus the ventral colouration is blackish with fine white dots and, as a consequence, the black dots can rarely be seen. The white dots of $T$. m. pygmaeus are relatively larger and more irregular than those of $T$. m. marmoratus; usually they are concentrated especially at the flanks, covering large surfaces, while in $T$. m. marmoratus the white dots are spread all over the ventral region.

- Dorsal crest: relatively low, linear and without any pelvic inflexion in $T . m$. pygmaeus; relatively high (especially in the central body area), crenulated and with an evident inflexion in the pelvic region in $T$. m. marmoratus.

Representative males and females of $T . m$. pygmaeus populations (Algeciras Bay, Cádiz) and $T$. m. marmoratus populations (Cantabria) are shown in Fig. 1.

Intrasubspecific variation. - Some intrasubspecific variation was observed in features such as size, dorsal colouration and the extent of the ventral white dotting. $T . m$. pygmaeus populations from the south of the province of Huelva (Doñana, El Rocío) clearly show a smaller size than those from the province of Cádiz. Populations from the provinces Cáceres, Ciudad Real, Toledo, and Madrid show a peculiar dorsal pattern, consisting of round black spots on a green background; these spots, generally abundant and never fused, give them a dotted ap- pearance, rather different from the marbled pattern typical of Cádiz populations. Dotted specimens generally show rounder snouts and shorter digits. In the Portuguese population of Portocovo the ventral white dots are limited to the periphery of the belly. In some populations from the provinces Madrid, Sevilla, and Cáceres, the white dots have low densities. The distribution of ventral white dots does not seem to follow any obvious geographical trend.

Slight variations were observed in the dorsal colouration of $T$. $m$. marmoratus with big round spots prevailing in the populations from La Rioja. We have also observed conspicuous individual differences in ventral background colouration; specimens showing light marbled areas have occasionally appeared in some populations from Salamanca and Madrid.

\section{Cytogenetic analysis}

Triturus marmoratus has 24 biarmed chromosomes of decreasing length, all of them sub- or metacentric. As Mancino \& Nardi (1971), Callan \& Lloyd (1975), Sims et al. (1984) and many other authors noticed, this species shows a fixed heteromorphism in chromosome 1, with the long arm of one of the chromosomes being considerably longer than that of the other chromosome (Fig. 2).

All individuals except those from Doñana presented the following C-bands pattern:

The chromosomes of $T$. marmoratus have large and very distinct centromeric C-bands, with the exception of chromosome 9 which has small centromeric C-bands (Fig. 2). All chromosomes have pericentric C-bands in both arms, except the long arm of pair 5 and the short arm of pair 12. Interstitial thin C-bands appear in the long arm of chromosome 7 and in the short arms of chromosome 4.

Terminal heterochromatin may be detected on the long arms of chromosomes 3, 4, 5, 8, and 9. Pair 4 constitutes the sexual chromosomes. Males show a C-band heteromorphism at the ends of the long arms. Chromosome $\mathrm{Y}$ has more terminal heterochromatin than chromosome $\mathrm{X}$ (Fig. 2). The long arms of chromosome 1 show two C-band heteromorphisms in all individuals, irrespective of sex. A large heterochromatic region, extending from 

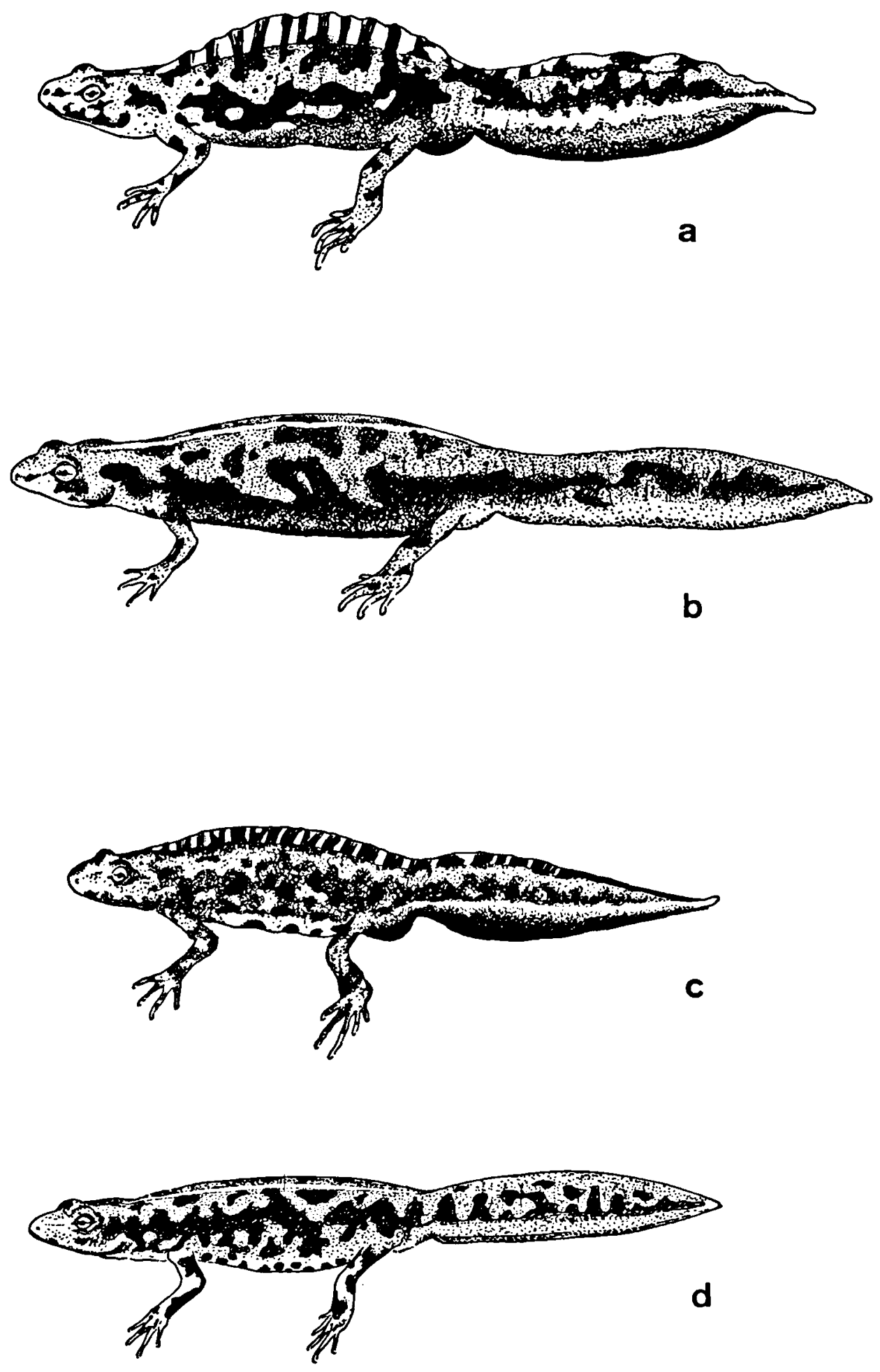

Fig. 1. Representative males (a) and females (b) from T. m. marmoratus (Cantabria, Spain) and T. m. pygmaeus (Algeciras Bay, Cádiz Province, Spain) (c, d). 

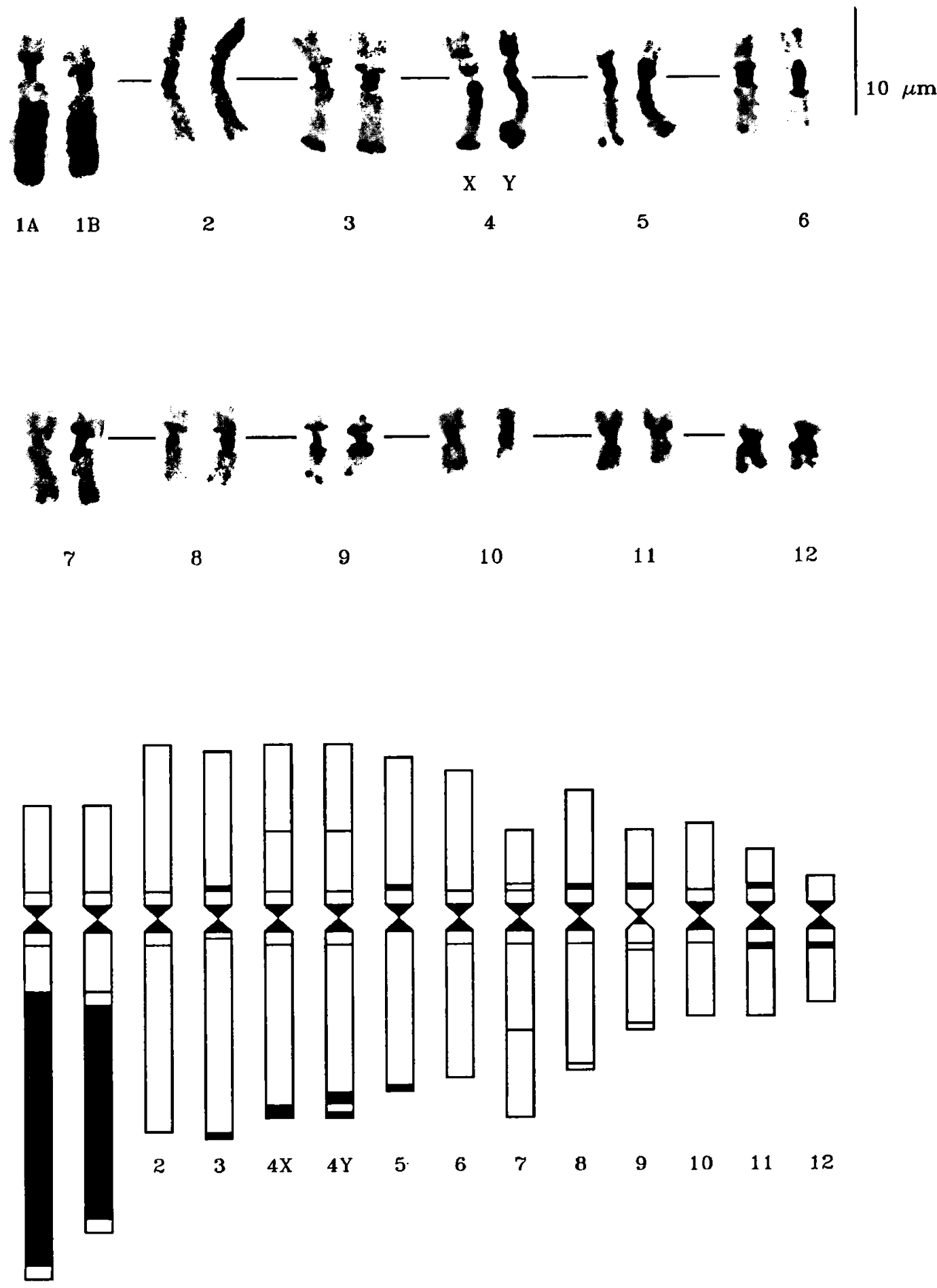

$1 \mathrm{~A} \quad 1 \mathrm{~B}$

Fig. 2. C-banded karyotype and idiogram representing the distribution of C-bands in the mitotic chromosomes of T. marmoratus. 


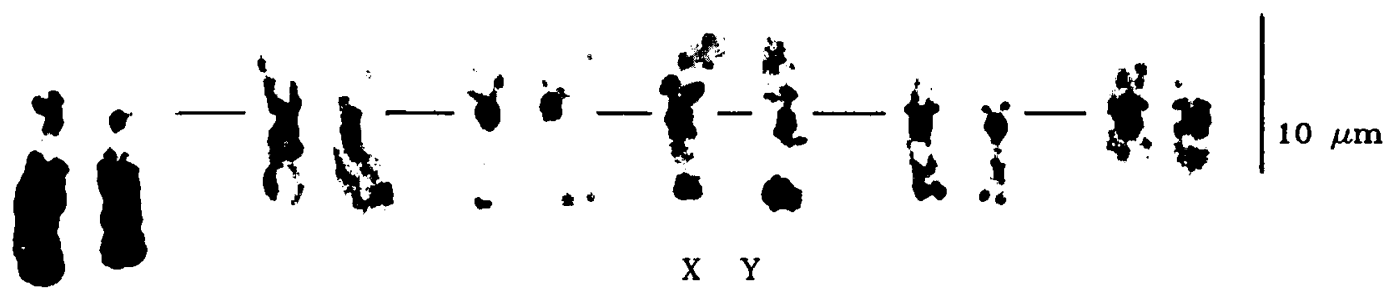

1A $1 \mathrm{~B}$

2

3

4

5

6

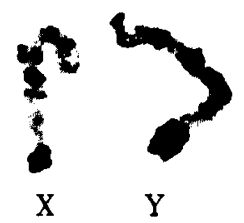

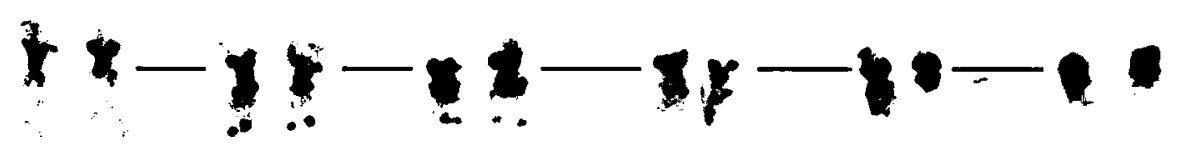

7

8

9

10

11

12

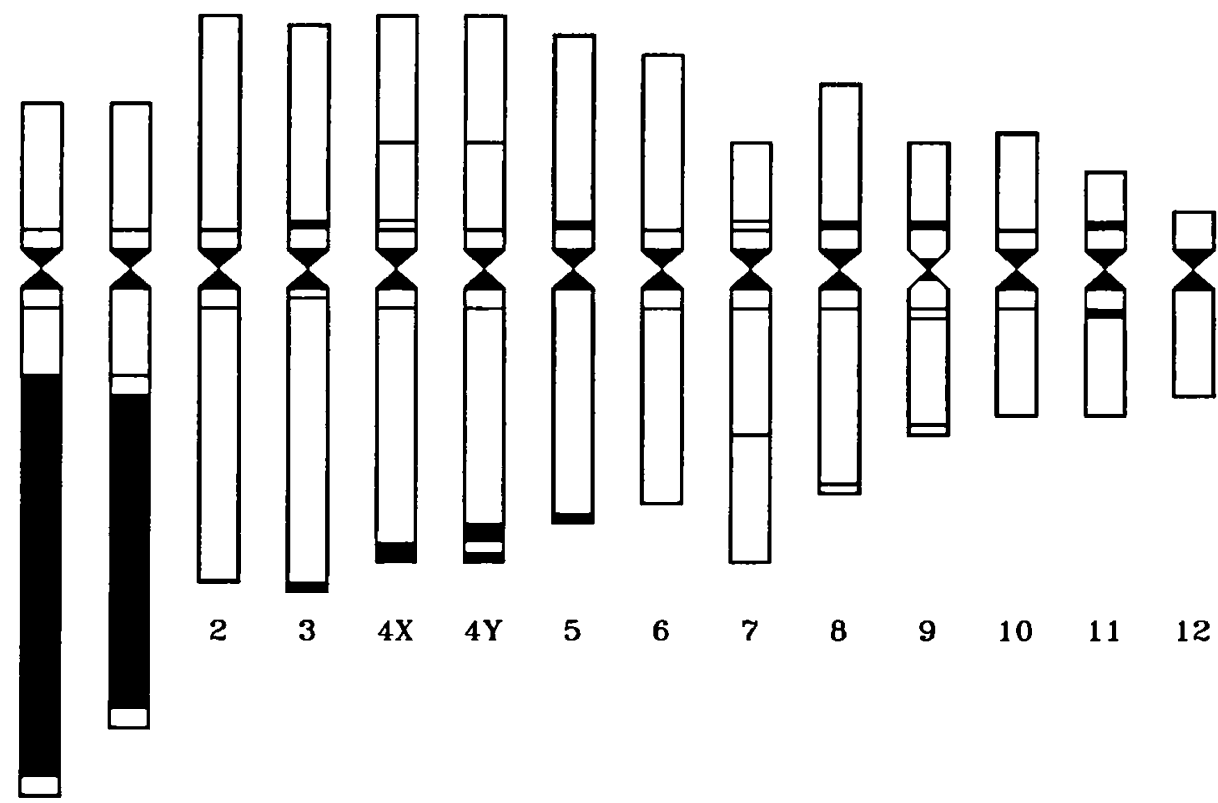

1A $1 \mathrm{~B}$

Fig. 3. C-banded karyotype and idiogram representing the distribution of C-bands in the mitotic chromosomes of a T. marmoratus individual from Doñana. Chromosome $4 \mathrm{X}$ shows a double pericentric band in the short arm. 
near the centromere to near the end, is present on these arms. This region is more extensive on the long chromosome 1A than on the short chromosome 1B. The pericentric C-band of chromosome $1 \mathrm{~A}$ is close to the centromere, whereas in chromosome $1 \mathrm{~B}$ it is close to the large heterochromatic region (Fig. 2). These results are in agreement with those described by Sims et al. (1984).

The population from Doñana is unique in that all individuals show two small but fixed differences on their C-banded chromosomes. These differences are: the absence of the pericentric band in the long arms of chromosome 12 and the presence of a double pericentric band in the short arms of chromosome X (Fig. 3).

\section{Distribution}

One of the main problems in studying Iberian populations of $T$. marmoratus has been the difficulty in assigning individuals to one of the two subspecies, due to the abbreviated original description of $T . m$. pygmaeus by Wolterstorff (1905).

According to the diagnostic features described above, we assigned all specimens examined to one of the two subspecies (Fig. 4) and the following distribution pattern was inferred:

The distribution of $T$. $m$. pygmaeus ranges along the southern half of the Iberian Peninsula (except in the eastern areas, where $T$. marmoratus seems to be absent), reaching at some places the southern slopes of the Sistema Central, which runs across the central region of the Iberian Peninsula. At one point (Puerto de Malagón, El Escorial, in the province of Madrid, Spain), the northern range of T. $m$. pygmaeus seems to reach beyond the Sistema Central.

The southern distributional limits of T. m. marmoratus reach beyond the Sistema Central and cover the southern slopes of mountains in the following three zones: the eastern part of the Sierra de Guadarrama, in the province of Madrid (Spain); Sierra de Gata, in the province of Cáceres (Spain); and Serra da Estrela, in the province of Beira Baixa (Portugal).

Comparing those distributions with the regions and bioclimatic areas proposed for the Iberian
Peninsula (Rivas Martínez, 1973; 1982), the distribution of $T$. m. marmoratus in the Iberian Peninsula seems to be coincident with the extension of the Eurosiberian region and the Supramediterranean bioclimatic area of the Mediterranean region. The Supramediterranean area is characterized by an annual mean temperature of 8 to $12^{\circ} \mathrm{C}$ and mean minimum and maximum temperatures in the coldest month of -3 to $0^{\circ} \mathrm{C}$ and 3 to $8^{\circ} \mathrm{C}$, respectively (Rivas Martínez, 1982). There are some exceptions in the mountains, where they reach the Oromediterranean area, and in the Ebro and Duero valleys as well as in some zones at the southern slopes of the Sistema Central, where they reach the Mesomediterranean bioclimatic area.

The distribution of T. m. pygmaeus is mostly included within the Mesomediterranean bioclimatic area, characterized by an annual mean temperature of 12 to $16^{\circ} \mathrm{C}$ and mean minimum and maximum temperatures in the coldest month of 0 to $5^{\circ} \mathrm{C}$ and 8 to $13^{\circ} \mathrm{C}$, respectively (Rivas Martínez, 1982). There are also populations of this taxon in the Thermomediterranean area of the Guadalquivir valley and the southern coast of Portugal and in the Supramediterranean area of some central and southern mountains.

The ecological characteristics of the breeding sites used by both $T$. m. marmoratus and T. m. pygmaeus are difficult to generalize as a consequence of the great variety showed by both taxa along the

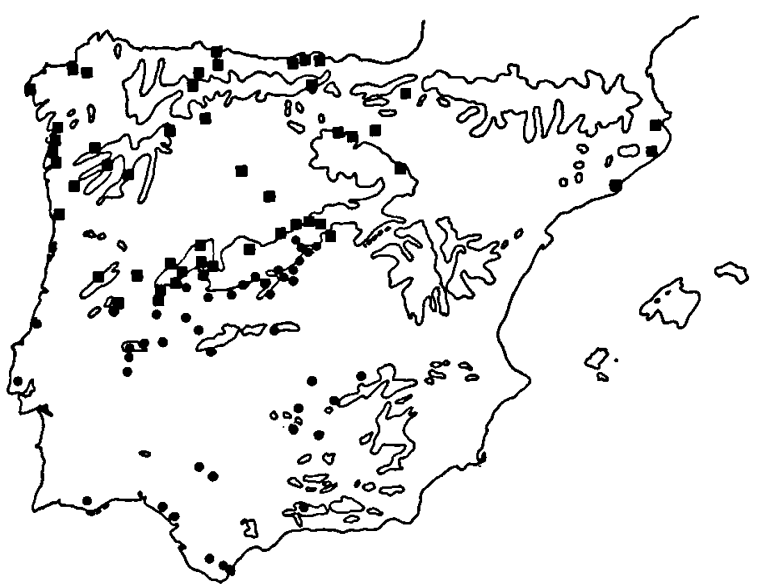

Fig. 4. Map of localities of material examined. T. m. marmoratus localities are represented by squares and $T$. $m$. pygmaeus localities by dots. 

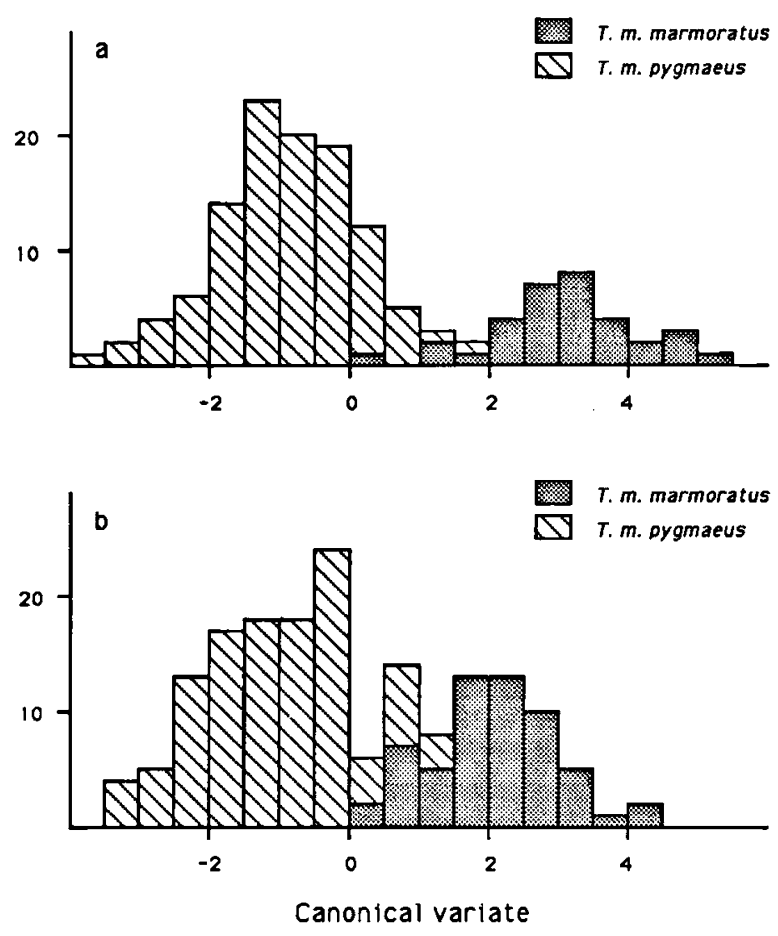

Fig. 5. Histogram of canonical variates for male (a) and female (b) $T$. marmoratus subspecies generated from the two-group discriminant analysis, conducted using natural-log transformed data.

whole area occupied. In general, both use small rivers, ponds in forested areas, man-made ponds for cattle in grassland areas, troughs, quarries, ditches in agricultural lands, mountain ponds, etc. In the border area of both taxa at the Sistema Central they use similar ponds, located on a granite sandy soil with different degrees of vegetational cover. In those areas, $T$. $m$. marmoratus seems to be found most frequently in the Supramediterranean area, corresponding with the potential oak forest of Quercus pyrenaica, and T. m. pygmaeus in the Mesomediterranean or Supramediterranean, corresponding to the potential forest of Quercus ilex.

\section{Discussion}

As a consequence of these results, the distributional map of $T . M$. pygmaeus should be extended from the only existing records referring to Cádiz and Huelva (Salvador, 1974; Collado et al., 1976) to their contact zone with the southernmost limits known for T. m. marmoratus (Dorda \& Esteban, 1986), along the Central Range Mountains (Sistema Central), as Macgregor et al. (1990) represented in their Fig. 1.

In the zones where the southern distributional range of $T$. $m$. marmoratus reaches beyond the Sistema Central, a contact area between the two subspecies is to be expected. However, we have so far failed in our search for individuals with intermediate characters, and no areas with strictly sympatric populations have yet been found. The closest populations with no apparent geographic barriers between them are separated by $6 \mathrm{~km}$ in the Sierra de Gata zone, and by $20 \mathrm{~km}$ in the Sierra de Guadarrama zone (Fig. 4).

This new distribution is in line with the geographical data arising from the biochemical analysis given by J.W. Arntzen, in Dorda \& Esteban (1986) (Nei's Distance $D=0.25$ between El Berrueco and Villalba populations), and Macgregor et al. (1990) (Nei's Distance $D=0.19$ between Balenyá and Lisboa populations), because, according to our data, the populations from Balenyá (Barcelona, Spain) and El Berrueco (Madrid, Spain) belong to $T$. m. marmoratus, while those from Villalba (Madrid, Spain) and Lisboa (Portugal) belong to the subspecies $T . m$. pygmaeus.

Nei's distances shown by these authors indicate clear differentiation between $T . m$. marmoratus and $T . m$. pygmaeus. In the present study this is reflected by some remarkable morphological differentiation in features associated with reproduction, and in size. This result is confirmed by the discriminant analysis carried out $a$ posteriori (Fig. 5). However, the interpopulational variability observed in many other features, considered not to be diagnostic, deserves further analysis. Possibly geographical trends in the observed patterns will be revealed.

The cytogenetic analysis does not show any intrasubspecific differentiation, with the exception of the Donana population. From a chromosomal point of view the characteristics shown by this species are among the most conservative within the 
genus Triturus (Herrero, 1985). Recent data on the cytogenetics of $T$. marmoratus seems to have led to some confusion, perhaps because different idiograms were drawn from the same C-banded preparations (cf. Sims et al., 1984 and Macgregor et al., 1990 , with the present study). We conclude that the morphological and biochemical differentiation achieved by $T$. $m$. pygmaeus populations is not paralleled at the chromosomal level.

As no strict sympatry has yet been observed, and individuals with an intermediate appearance between both subspecies have not been found, it is necessary to study the potential areas of contact in more detail. Studies in the areas of Avila, Cáceres, and Madrid provinces (Spain), and in Beira Baixa and Estremadura (Portugal) would be particularly interesting, so as to ascertain the degree of differentiation and isolation achieved by the two forms. The potential existence of a narrow contact zone, with gene flow absent or very low, poses the question whether $T$. $m$. pygmaeus should be assigned specific status.

\section{Acknowledgements}

We are indebted to I. Esteban, A. Múgica, and F. Barrios for their valuable cooperation in the fieldwork; to Dr. J.W. Arntzen for sending us some of his material and for helpful suggestions; to Prof. E.G. Crespo who gave us access to the collections of Museu Bocage; to L. van Tuyl for providing us with material from the Zoölogisch Museum, Amsterdam; to the "Agencias de Medio Ambiente" from the "Comunidades Autónomas" of Andalucía, Asturias, Castilla - La Mancha and Madrid for authorizing us to capture specimens from areas not represented in museum collections; to C. Hosie, A. Smidthson, and L. García-Hidalgo for helpful linguistic suggestions. This work was supported by CICYT Project PB 88-0010 and the CSIC - British Council Cooperative Project (Spain-Great Britain) HB-180.

\section{References}

Andrada, J., 1980. Guía de campo de los anfibios y reptiles de la Península Ibéríca: 1-51 (Omega, Barcelona).

Busack, S.D., B.G. Jericho, L.R. Maxson \& T. Uzzell, 1988. Evolutionary relationships of salamanders in the genus Triturus: The view from immunology. Herpetologica, 44: 307316.

Callan, H.G. \& L. Lloyd, 1975. Working maps of the lampbrush of Amphibia. In: R.C. King (ed.), Handbook of genetics, 4: 57-77 (Plenum, New York).
Collado, E., J. Calderon \& M. Pérez, 1976. Datos sobre la fauna de anfibios del Bajo Guadalquivir. Doñana, Acta Vertebrata, 3(1): 5-17.

Dixon, W.J. (ed.), 1983. BMDP Statistical Software: 1-733 (Univ. California Press, Berkeley).

Dorda, J. \& M. Esteban, 1986. Evolution and subspeciation of Iberian Triturus marmoratus. In: Z. Rocek (ed.), Stud. Herpetol., Prague: 159-163.

Herrero, P., 1985. Estudios citogenéticos en las especies del género Triturus de la Península Ibérica: 1-147 ( Ph. D. Thesis, Universidad Autónoma de Madrid).

Lemen, C., 1983. The effectiveness of methods of shape analysis. Fieldiana, Zool., 1343: 1-17.

Macgregor, H.C., S.K. Sessions \& J.W. Arntzen, 1990. An integrative analysis of phylogenetic relationships among newts of the genus Triturus (family Salamandridae), using comparative biochemistry, cytogenetics and reproductive interactions. J. evol. Biol., 3: 329-373.

Mancino, G. \& I. Nardi, 1971. Chromosomal heteromorphism and female heterogamety in the marbled newt Triturus marmoratus (Latreille, 1800). Experientia, 27: 821-822.

Mertens, R. \& L. Müller, 1928. Die Amphibien und Reptilien Europas. Zweite liste. Abh. senckenb. naturf. Ges., 41: 1-62.

Rivas-Martínez, S., 1973. Avance sobre una síntesis corológica de la Península Ibérica, Baleares y Canarias. Anal. Inst. Bot. Cavanilles, 33: 167-188.

Rivas-Martínez, S., 1982. Mapa de las series de vegetación de Madrid (Diputación de Madrid, Madrid).

Salvador, A., 1974. Guía de los anfibios y reptiles de España: 1-237 (ICONA, Madrid).

Sims, S.H., H.C. Macgregor, P.S. Pellat \& H.A. Horner, 1984. Chromosome 1 in crested and marbled newts (Triturus). An extraordinary case of heteromorphism and independent chromosome evolution. Chromosoma, 89: 169-185.

Sumner, A.T., 1972. A simple technique for demonstrating centromeric heterochromatin. Exp. Cell Res., 75: 304-306.

Wolterstorff, W., 1905. Zwergformen der Paläarktischen Urodelen. C. r. 6e Congr. int. Zool., Berne: 258-263.

Zar, J.H., 1984. Biostatistical analysis (2nd ed.): 122-149 (Prentice Hall, Inc., New Jersey).

Received: 27 February 1992

Revised: 27 October 1992

\section{Appendix}

Material examined

(a) Museum collections:

The acronyms used are the following: $\mathrm{MNCN}=$ Museo Nacional de Ciencias Naturales (Madrid, Spain); MBL = Museu Bocage (Lisboa, Portugal); ZMA = Zoölogisch Museum Amsterdam (Amsterdam, The Netherlands); BMNH = British Museum (Natural History) (London, U.K.); ct indicates that the specimen was cytogenetically analyzed. 


\section{T. m. marmoratus:}

PORTUGAL: Cabeço do Infante: 3 specimens, MNCN 9777-79; Freixadas-Alverca: 1 specimen, MBL.

Beira Alta: Serra da Estrela: 1 specimen, MNCN 2425; Vilar Formoso: 1 specimen, ZMF 7281.

Beira Baixa: Castelo Branco: 3 specimens, MNCN 9783-85. Douro Litoral: Valongo: 1 specimen, ZMF 7682.

Minho: Braga: 2 specimens, MNCN 777-78; Geres - Braga: 5 specimens, MBL; Bom Jesus (Braga): 3 specimens, MBL.

Tras-os-Montes: Serra da Nogueira (sur de Bragança): 1 specimen, MBL; Rebordãos, Serra da Nogueira, 1 specimen, MBL.

SPAIN: Asturias: Oviedo: 10 uncatalogued specimens (ct), 1 specimen, MNCN 767, 1 specimen, MNCN 9593; Posada: 1 specimen, MNCN 847; La Muela - Pola de Lena: 3 specimens, MNCN 9595-97; Pola de Siero: 5 uncatalogued specimens (ct), 2 specimens, MNCN 11197-98; Gijón: 16 uncatalogued specimens (ct), 10 specimens, MNCN 790-99, 5 specimens, MNCN 819-23; Asturias: 1 specimen, MNCN 766.

Avila: Avila: 4 specimens, MNCN 2402-05.

Barcelona: Barcelona: 1 specimen, ZMF 7637.

Burgos: Bujedo: 1 specimen, MNCN 757; Pancorbo: 8 specimens, MNCN 11112-19.

Cantabria: Santillana del Mar: 10 uncatalogued specimens (ct), 6 specimens, MNCN 11189-94, 5 specimens, MNCN 13072-76, 1 specimen, MNCN 13265, 1 specimen, MNCN 15337, 3 specimens, MNCN 16095-97; Oreña: 9 specimens, MNCN 13077-85, 6 specimens, MNCN 16089-94; Lago Revilla: 3 specimens, MNCN 2433-35; Embalse del Ebro - Reinosa: 2 uncatalogued specimens (ct), 1 specimen, MNCN 15336; Santander: 3 uncatalogued specimens (ct), 1 specimen, MNCN 16098.

Gerona: Tosa: 5 uncatalogued specimens (ct).

La Coruña: La Coruña: 1 specimen, MNCN 758, 1 specimen, MNCN 800, 13 specimens, MNCN 806-18; Los Castros, 12 specimens, MNCN 824-35; Santa María de Ois: 1 specimen, MNCN 15338.

La Rioja: Logroño: 2 specimens, MNCN 804-05, 1 specimen, MNCN 9406; Valgañón: 1 specimen, MNCN 16066.

León: Foncebadón: 2 uncatalogued specimens (ct); León: 2 specimens, MNCN 2427-28.

Madrid: El Berrueco: 8 uncatalogued specimens (ct), 2 specimens, MNCN 9589-90, 2 specimens, MNCN 9591-92, 1 specimen, MNCN 9594, 9 specimens, MNCN 13062-70, 2 specimens, MNCN 15340-41, 6 specimens, MNCN 16068-73; El Paular: 3 specimens, MNCN 2468-70, 3 specimens, MNCN 2472-74, 3 specimens, MNCN 2476-78; La Cabrera: 2 specimens, MNCN 15322-23, 1 specimen, MNCN 15344, 3 specimens, MNCN 15944-46.

Navarra: Pamplona: 2 specimens, MNCN 836-37.

Orense: Orense: 4 specimens, MNCN 779-82.

Pontevedra: Vigo: 1 specimen, MNCN 2432; Tuy: 2 specimens, MNCN 775-76; Pontevedra: 1 specimen, MNCN 768; Moaña: 6 uncatalogued specimens (ct), 1 specimen, MNCN 16067.

Salamanca: Montemayor del Río: 1 specimen, MNCN 9588; Robleda: 6 specimens, MNCN 769-74.
Segovia: La Granja: 3 specimens, MNCN 783-85.

Valladolid: Valladolid: 2 specimens, MNCN 838-39.

Zamora: Fuentes de Ropel: 15 uncatalogued specimens (ct).

Zaragoza: Tarazona: 3 uncatalogued specimens $(\mathrm{ct})$.

\section{T. m. pygmaeus:}

PORTUGAL: Beira Baixa: Castelo Branco - Escalos de Baixo: 1 specimen, MBL.

Estremadura: Lagoas do Arrimal - Porto de Mos: 4 specimens, MBL; Sintra: 2 specimens, MBL; Sintra: 2 specimens, BMNH 189632668; Palace Grounds of Quiluz, 1 specimen, BMNH 18767767.

Algarve: Tavira, N 270 km 58.8: 3 specimens, MBL.

Alto Alemtejo: Portalegre - Castelo de Vide: 5 specimens, MBL; Estremoz: 2 specimens, MNCN 9780-81; Vimiciro: 3 specimens, MBL; Cabeçao: 2 specimens, MBL; Serra de São Mamede (Portalegre): 1 specimen, MBL.

SPAIN: Avila: Piedralaves - Mijares: 3 uncatalogued specimens (ct), 4 specimens, MNCN 9581-84.

Cáceres: Villanueva de la Vera: 9 uncatalogued specimens (ct), 2 specimens, MNCN 9603-04; Trujillo: 2 specimens, MNCN 9782, 15339; Robledollano: 1 specimen, MNCN 2426; Villa Real de San Carlos: 5 uncatalogued specimens (ct), 2 specimens, MNCN 13071, 15334.

Cádiz: Los Barrios: 6 specimens, MNCN 15313-18 (ct), 7 specimens, MNCN 15319-21, 15331-32, 15949-50, 1 uncatalogued specimen; San Roque: 1 specimen, MNCN 15948.

Ciudad Real: Daimiel: 4 specimens, MNCN 1014-16, 1018; Ruidera: 2 specimens, MNCN 845-46; Río Tablillas: 1 specimen, MNCN 15932.

Córdoba: Venta del Charco: 10 specimens, ZMA 7677, 4 specimens, ZMA 8046.

Granada: Zafarraya: 25 specimens, MNCN 15299-306, 15335, 15951-55, 11 uncatalogued.

Huelva: Doñana: 8 uncatalogued specimens (ct); 5 specimens, MNCN 11217, 15333, 16086-88.

Jaén: Jaén: 1 specimen, MNCN 11195.

Madrid: Hoyo de Manzanares: 2 specimens, MNCN 9601-02, 1 specimen, MNCN 11199, 6 specimens, MNCN 15307-12, 7 specimens, MNCN 15324-30, 10 specimens, MNCN 15956-65, 3 specimens, MNCN 16077-79; Villalba: 4 uncatalogued specimens (ct), 2 specimens, MNCN 9570-71, 2 specimens, MNCN 13053-54; Alpedrete: 2 uncatalogued specimens (ct); Pantano de San Juan: 1 specimen, MNCN 9585; Torrelodones: 10 uncatalogued specimens (ct), 2 specimens, MNCN 9586-87, 1 specimen, MNCN 15343, 3 specimens, MNCN 16074-76; Chapinería: 3 specimens, MNCN 9575-77; Navalagamella: 3 specimens, MNCN 9572-74, 7 specimens, MNCN 13055-61; El Pardillo: 4 specimens, MNCN 786-89.

Sevilla: Gerena: 5 uncatalogued specimens (ct), 2 specimens, MNCN 9599-9600, 11 specimens, MNCN 13085-95, 2 specimens, MNCN 16080-81; Sevilla: 2 specimens, MNCN 2422-23. Toledo: Nombela: 3 specimens, MNCN 9578-80; Navalcán: 1 specimen, MNCN 2421; Pelahustán: 8 uncatalogued specimens (ct), 7 specimens, MNCN 11218-24. 
(b) Sites not mentioned in the former list, where individuals were observed and later freed in situ:

\section{T. m. marmoratus:}

SPAIN: Avila: Avila.

Cáceres: Hervás, Perales del Puerto, Valverde del Fresno, Cilleros, Santibañez el Alto.

Cantabria: Noja.

Gerona: Roses.

La Coruña: Finisterre.

Madrid: Peñalara, Rascafría.

Pontevedra: Cutián.

Salamanca: El Cabaco, El Maillo, Candelario.

Segovia: El Espinar, Villacastín.
T. m. pygmaeus:

SPAIN: Avila: Mijares, Candeleda, La Adrada.

Cáceres: Navalmoral de la Mata, Lanchares (Valencia de Alcántara), Logrosán, Herreruela, Torrejoncillo, Zarza la Mayor, Pozuelo de Zarzón.

Cádiz: Alcalá de los Gazules.

Ciudad Real: El Viso del Marqués.

Huelva: El Rocío.

Madrid: Puerto de Malagón, El Escorial, Zarzalejo, Valdemorillo, Cenicientos, Pelayos de la Presa, Cadalso de los Vidrios, Colmenar Viejo, Becerril, Cerceda, Valdemaqueda, Colmenar del Arroyo.

Toledo: San Pablo de los Montes. 